\title{
PENGARUH LATIHAN UP HILL TERHADAP KEKUATAN SHOOTING DALAM PERMAINAN SEPAKBOLA PADA CLUB ABADI TALISE
}

\author{
Moh. Saldi Fauzi ${ }^{1}$, Abu Bakar ${ }^{2}$ \\ Universitas Muhammadiyah Luwuk \\ abubakar06591@gmail.com
}

\begin{abstract}
Abstrak
Permasalahan utama dalam penelitian ini kurangnya kekuatan shooting dalam permainan sepak bola pada $c l u b$ Abadi Talise. Tujuan dari penelitian ini adalah untuk mengetahui seberapa besar pengaruh latihan up hill terhadap kekuatan shooting dalam permainan sepak bola pada club Abadi Talise. Penelitian ini termaksud penelitian kuantitatif. Metode yang digunakan dalam penelitian ini adalah metode eksperimen. Populasi yang dimaksud dalam penelitian ini adalah seluruh atlet yang berada di club sepakbola Abadi Talise yang berjumlah 20 orang, dengan menggunakan teknik studi populasi. Teknik analisis data yang digunakan adalah teknik analisis deskriptif dan infersial dengan menggunakan program SPSS Versi 16.00 pada taraf signifikan 95\% atau $\alpha 0,05$. Hasil penelitian menyimpulkan bahwa: peningkatan kekuatan shooting dengan menggunakan metode latihan up hill dibuktikan dengann nilai selisih rata-rata 281,21 - 252,81 dengan hasil tersebut menunjukkan peningkatan nilai rata-rata 28,4 setelah perlakuan dengan metode latihan up hill atlet sepak bola pada club Abadi Talise dan diharapkan pemberian latihan up hill harus lebih diperhatikan dalam melakukan pelatihan pada cabang olahraga sepakbola, khususnya dalam melakukan shooting.
\end{abstract}

Kata Kunci : Latihan Up Hill, Kekuatan Shooting, Sepak Bola.

\begin{abstract}
The problem of this research was whether there is an effect of up hill training toward the shooting power. The purpose this research is finding out the effect of up hill training toward the shooting power in soccer game at Talise Abadi Club. This was an experimental research using pre-test and post-test design. This research was conducted at Talise Abadi Club. The subject of the reserch was 20 players of Talise Abadi Club divided into experimental and control groups. The data were collected through power test which is a shooting power test in soccer game. Based on the inferential analysis by using $t$-test, it found that in relation to the up hill trainings, $t_{\text {test }}=17.64$ with $t_{\text {table }}$ in the level of significance of $5 \%$ d.b $=(N-1)(10-1)=9$ is 2.268. Therefore, the $t_{\text {test }}$ is higher than the table $(17.64>2.268$. It can be said that null hypothesis $(\mathrm{Ho})$ is rejected and alternative hypothesis $(\mathrm{Ha})$ is accepted. It means that there is a significant effect of up hill training toward the soccer game. In conclusion, up hill training can improve the shooting power in soccer game at Talise Abadi Club. The result of this research is expected to be an additional reference for trainers in the process of training as well as giving sufficient portion of up hill training.
\end{abstract}

\section{Key Words: Up Hill Training, Shooting Power, Soccer}

Dipublikasikan Oleh :

UPT Publikasi dan Pengelolaan Jurnal

Universitas Islam Kalimantan Muhammad Arsyad Al-Banjari Banjarmasin 


\section{PENDAHULUAN}

Olahraga merupakan hal yang sangat dekat dengan manusia kapan dan dimana saja berada. Sebab olahraga merupakan salah satu kebutuhan hidup yang harus dipenuhi oleh setiap manusia. Olahraga menempati salah satu kedudukan terpenting dalam kehidupan manusia. Dalam kehidupan modern sekarang ini manusia tidak bisa dipisahkan dari kegiatan olahraga baik sebagai salah satu pekerjaan khusus, sebagai tontonan, rekreasi, mata pencaharian, kesehatan maupun budaya.

Salah satu cabang olahraga yang saat ini sangat diminati oleh seluruh lapisan masyarakat, terutama kaum muda adalah olahraga sepakbola. Hal ini disebabkan karena olahraga sepakbola hanya memerlukan peralatan yang sederhana serta mendatangkan kesenangan bagi yang bermain.

Olahraga sepakbola yang dimainkan oleh dua regu yang saling berlawanan ini dapat dimainkan oleh siapa saja, baik anak-anak, usia muda maupun tua. Sepak bola bukan merupakan permainan yang bersifat perseorangan akan tetapi merupakan permainan yang bersifat beregu. Tiap-tiap regu terdiri dari atas 11 orang, sehingga harus ada kerjasama antar pemain untuk menghasilkan kemenangan. Meskipun tim terdiri atas pemain yang memiliki keterampilan dan teknik yang baik tetapi tidak memiliki kemampuan kolektif antara pemain, maka tidak menjadi jaminan tim tersebut akan menjadi tim yang solid.

Menendang bola adalah hal yang paling mendasar dalam bermain sepakbola. Oleh karena itu setiap pemain bola harus terus melatih dan mengasah kemampuan mereka dalam menendang bola, baik itu menendang bola dengan pelan maupun menendang bola dengan kencang atau kuat. Dalam menendang bola setiap pemain bola harus dapat menjaga keseimbangan, posisi kaki yang tepat dan kekuatan kaki dalam menendang, khususnya menendang bola dengan kencang dan kuat. Kekuatan otot tungkai sangatlah dibutuhkan untuk meningkatkan kekuatan power shooting. Bentuk-bentuk latihan pun bervariasi. Pada umumnya pelatih-pelatih sepakbola kurang mengetahui metode latihan untuk meningkatkan kekuatan shooting, Padahal ada beberapa metode untuk meningkatkan kekuatan shooting, diantaranya adalah latihan beban dan latihan pliometrik.

Berbagai bentuk latihan sudah mulai dikembangkan pada saat ini. Dalam penelitian ini penulis memilih bentuk latihan up hill. Latihan up hill adalah latihan lari yang dilakukan naik bukit, dengan tujuan untuk meningkatkan kekuatan otot-otot tungkai kaki, latihan ini dilakukan secara berulang-ulang minimal dalam beberapa hari. Adapun yang menjadi bahan penelitian penulis adalah "Pengaruh Latihan Up Hill Terhadap Kekuatan Shooting Dalam Permainan Sepakbola Pada Club Abadi Talise".

Berdasarkan latar belakang di atas, penulis dapat merumuskan masalah dalam penelitian ini apakah ada Pengaruh Latihan Up Hill Terhadap Kekuatan Shooting Dalam Permainan Sepakbola Pada Club Abadi Talise?. Sesuai dengan perumusan masalah yang disusun, maka 
penelitian ini bertujuan untuk mengetahui seberapa besar pengaruh latihan up hill terhadap kekuatan shooting dalam permainan sepak bola pada club Abadi Talise.

\section{METODE}

Populasi merupakan keseluruhan subyek penelitian (Arikunto, 2006:130). Adapun populasi yang menjadi subyek dalam penelitian ini adalah 20 atlet yang ada di club Sepakbola Abadi Talise. Sampel merupakan sebagian dari populasi yang di selidiki, yang generalisasinya (kesimpulannya) dikenakan terhadap semua individu atau populasi. Sampel adalah sebagian atau wakil populasi yang di teliti (Arikunto, 2006:131). Teknik pengambilan sampel dalam penelitian ini adalah subjek penelitian. Sehingga sampel dalam penelitian 20 atlet yang terbagi dalam dua kelompok yaitu 10 kelompok eksperimen dan 10 kelompok kontrol.

Penelitian di laksanakan di lapangan Abadi Talise Kelurahan Talise Kecamatan Mantikulore. Penelitian di lakukan selama 6 minggu, setiap minggu tiga kali pertemuan. Data yang akan dikumpulkan dalam penelitian ini yakni data tes awal dan tes akhir kekuatan shooting setelah diberikan latihan up hill dengan kemiringan gunung $45^{\circ}$ dengan jarak mendaki 30 meter.

Teknik pengambilan data dilaksanakan dengan tes dan pengukuran, untuk memperoleh data yang objektif tentang hasil latihan pemain. Melalui pengukuran kita akan memperoleh informasi yang objektif sehingga kita dapat menentukan prestasi seseorang pada saat tertentu. Tes dan pengukuran dalam penelitian ini dilaksanakan untuk mendapatkan data tentang hasil shooting yang dilaksanakan dua kali yaitu pre-test (tes awal) dan post-test (tes akhir). Hasil tes di catat dalam satuan meter.

1) Tempat penelitian di laksanakan di lapangan Abadi Talise Kelurahan Talise Kecamatan Mantikulore.

2) Objek penelitian, atlet Sepakbola di club Sepak bola Kelurahan Talise Kecamatan Mantikulore.

3) Tenaga pembantu, untuk memperlancar jalannya penelitian, peneliti di bantu beberapa teman sajawat (mahasiswa) yang bertugas sebagai seksi dokumentasi.

4) Pelaksanaan penelitian secara keseluruhan, penelitian ini di laksanakan selama 6 minggu.

Analisis data yang di gunakan dalam penelitian ini adalah analisis inferensial dilakukan untuk menguji hipotesis yang diajukan dengan menggunakan teknik analisis t-test oleh (Hadi, 2001:490) dengan rumus sebagai berikut :

$$
t=\frac{M D}{\sqrt{\frac{d_{2}}{N(N-1)}}}
$$

Keterangan :

$\mathrm{MD}=$ Mean perbedaan pre-test dan post-test (Mean Deviasi)

$\sum d 2=$ Jumlah kuadrat deviasi perbedaan (Deviasi Individu dari MD) 
$\mathrm{N} \quad=$ Jumlah Subjek/Sampel

Mencari mean perbedaan (MD) digunakan rumus:

$$
\mathrm{MD}=\frac{\sum D}{N}
$$

Keteranagan :

$\sum D \quad=$ Jumlah perbedaan masing-masing subjek

$\mathrm{N} \quad=$ Jumlah subjek/sampel

Untuk dapat dikatakan signifikan pada tingkat kesamaan 5\%, maka nilai $\mathrm{t}$ hitung haruslah sama atau lebih besar dari t-tabel. Derajat kebebasan (db) dari t-test ini adalah N-1.

\section{HASIL DAN PEMBAHASAN}

Deskripsi data yang akan disajikan berupa data hasil tes kekuatan shooting sebelum (pretest) dan sesudah (post-test) diberikan perlakuan pada masing-masing kelompok yang meliputi: kelompok eksperimen I dan kelompok II (kontrol).

Tabel 1. Data Tes Awal dan Tes Akhir Kekuatan Shooting Kelompok Eksperimen Pada Club Abadi Talise.

\begin{tabular}{|c|l|c|c|}
\hline No & \multicolumn{1}{|c|}{ Nama } & $\begin{array}{c}\text { Tes Awal Kekuatan } \\
\text { Shooting }\end{array}$ & $\begin{array}{c}\text { Tes Akhir Kekuatan } \\
\text { Shooting }\end{array}$ \\
\hline 1 & AS & 24.20 & 26,70 \\
\hline 2 & AD & 26.27 & 29,77 \\
\hline 3 & AR & 26.30 & 28,80 \\
\hline 4 & AHR & 25.15 & 27,15 \\
\hline 5 & DR & 24.25 & 26,75 \\
\hline 6 & IW & 25.40 & 28,40 \\
\hline 7 & MA & 26.36 & 28,86 \\
\hline 8 & PR & 24.38 & 27,58 \\
\hline 9 & TR & 26.40 & 29,60 \\
\hline 10 & RH & 24.10 & 27,60 \\
\hline
\end{tabular}

Berdasarkan tabel 1 (tes awal) di atas kekuatan shootingkelompok eksperimen sebelum diberikan latihan up hilldari 10 orang sampel diperoleh shooting terjauh adalah 26,40 meter dan shooting terdekat adalah 24,10 meter. Sedangkan (tes akhir) di atas kekuatan shooting kelompok eksperimen sesudah diberikan latihan up hill diperoleh shooting terjauh 29,60 meter dan shooting terdekat 26,70 meter.

Tabel 2. Data Tes Awal dan Tes Akhir Kekuatan Shooting Kelompok Kontrol Pada Club Abadi Talise.

\begin{tabular}{|c|l|c|c|}
\hline No & \multicolumn{1}{|c|}{ Nama } & $\begin{array}{c}\text { Tes Awal Kekuatan } \\
\text { Shooting }\end{array}$ & $\begin{array}{c}\text { Tes Akhir Kekuatan } \\
\text { Shooting }\end{array}$ \\
\hline 1 & RF & 24.15 & 24,95 \\
\hline 2 & SP & 26.35 & 27,15 \\
\hline 3 & MA & 25.30 & 26,10 \\
\hline 4 & AV & 26.36 & 27,16 \\
\hline 5 & AS & 24.38 & 25,18 \\
\hline 6 & MF & 26.40 & 27,20 \\
\hline
\end{tabular}

Dipublikasikan Oleh : 


\begin{tabular}{|c|l|l|l|}
\hline 7 & RJ & 24.10 & 24,90 \\
\hline 8 & RT & 26.27 & 27,07 \\
\hline 9 & MAF & 26.30 & 27,10 \\
\hline 10 & AR & 25.15 & 25,95 \\
\hline
\end{tabular}

Berdasarkan tabel 2 (tes awal) di atas kekuatan shooting kelompok kontrol sebelum diberikan latihan up hill dari 10 orang sampel diperoleh shooting terjauh adalah 26,36 meter dan shooting terdekat adalah 24,10 meter. Sedangkan (tes akhir) di atas kekuatan shooting kelompok kontrol yang tidak diberikan latihan up hill diperoleh shooting terjauh 27,15 meter dan shooting terdekat 24,90 meter.

Uji analisis data merupakan prosedur yang harus dilaksanankan dan dipenuhi, sehingga kesimpulan yang diambil dari hasil analisis berbeda dengan yang dilakukan dan dapat dipertanggungjawabkan kebenarannya apabila syarat-syarat analisis telah terpenuhi. Persyaratan uji analisis data yang digunakan adalah uji normalitas.

Uji normalitas data digunakan untuk mengetahui data yang diperoleh apakah berdistribusi normal atau tidak.pengujian ini menggunakan rumus uji Kolmogorov-Smirnov dengan kreteria bahwa data berdistribusi normal apabila nilai signifikan atau nilai probabilitas K-S $>0,05$. Hasil perhitungan uji normalitas data tes awal dan tes akhir kedua kelompok terhadap kekuatan shooting dalam permainan sepak bola adalah sebagai berikut :

Tabel 3. Hasil uji normalitas data tes awal dan tes akhir kekuatan shooting dalam permainan sepak bola pada club Abadi Talise.

One-Sample Kolmogorov-Smirnov Test

\begin{tabular}{|c|c|c|c|c|c|}
\hline & & $\begin{array}{c}\text { Tes awal } \\
\text { kelompok } \\
\text { eksperimen }\end{array}$ & $\begin{array}{l}\text { Tes akhir } \\
\text { kelompok } \\
\text { eksperimen }\end{array}$ & $\begin{array}{c}\text { Tes awal } \\
\text { kelompok } \\
\text { kontrol }\end{array}$ & $\begin{array}{l}\text { Tes akhir } \\
\text { kelompok } \\
\text { kontrol }\end{array}$ \\
\hline \multicolumn{2}{|l|}{$\mathrm{N}$} & 10 & 10 & 10 & 10 \\
\hline \multirow{2}{*}{$\begin{array}{l}\text { Normal } \\
\text { Parameters }^{\mathrm{a}}\end{array}$} & Mean & 25.2810 & 27.5000 & 25.4760 & 25.9000 \\
\hline & $\begin{array}{l}\text { Std. } \\
\text { Deviation }\end{array}$ & .99456 & 1.08012 & .98312 & 1.28668 \\
\hline \multirow{3}{*}{$\begin{array}{l}\text { Most Extreme } \\
\text { Differences }\end{array}$} & Absolute & .240 & .178 & .290 & .304 \\
\hline & Positive & .218 & .178 & .174 & .196 \\
\hline & Negative & -.240 & -.178 & -.290 & -.304 \\
\hline \multicolumn{2}{|c|}{ Kolmogorov-Smirnov Z } & .759 & .564 & .918 & .960 \\
\hline \multicolumn{2}{|c|}{ Asymp. Sig. (2-tailed) } & .612 & .908 & .368 & .315 \\
\hline \multicolumn{2}{|c|}{$\begin{array}{l}\text { a. Test distribution is } \\
\text { Normal. }\end{array}$} & & & & \\
\hline
\end{tabular}

Berdasarkan tabel di atas yang merupakan rangkuman hasil pengujian normalitas data pada tiap-tiap variabel penelitian, dapat diuraikan sebagai berikut :

1. Pengujian normalitas data tes awal kelompok eksperimen terhadap kekuatan shooting dalam permainan sepak bola diperoleh nilai uji Kolmogorov-Smirnov Test 0,759 dengan tingkat 
probabilitas (P) 0,612 lebih besar dari pada nilai $\alpha$ 0,05. Dengan demikian data tes awal kekuatan shooting dalam penelitian ini mengikuti sebaran normal atau berdistribusi normal. Sedangkan Pengujian normalitas data tes akhir kelompok eksperimen terhadap kekuatan shooting dalam permainan sepak bola diperoleh nilai uji Kolmogorov-Smirnov Test 0,564 dengan tingkat probabilitas (P) 0,908 lebih besar dari pada nilai $\alpha 0,05$. Sehingga data tes akhir dalam permainan sepak bola pada club Abadi Talise mengikuti sebaran normal atau berdistribusi normal.

2. Pengujian normalitas data tes awal kelompok kontrol terhadap kekuatan shooting dalam permainan sepak bola diperoleh nilai uji Kolmogorov-Smirnov Test 0,918 dengan tingkat probabilitas (P) 0,368 lebih besar dari pada nilai $\alpha$ 0,05. Dengan demikian data tes awal kekuatan shooting dalam penelitian ini mengikuti sebaran normal atau berdistribusi normal. Sedangkan Pengujian normalitas data tes akhir kelompok kontrol terhadap kekuatan shooting dalam permainan sepak bola diperoleh nilai uji Kolmogorov-Smirnov Test 0,960 dengan tingkat probabilitas (P) 0,315 lebih besar dari pada nilai $\alpha$,05. Sehingga data tes akhir dalam permainan sepak bola pada club Abadi Talise mengikuti sebaran normal atau berdistribusi normal.

Setelah uji normalitas terlaksana, selanjutnya dapat digunakan uji parametrik dengan Uji t-tes.

Tabel 4. Selisih kekuatan shooting sebelum dan sesudah diberikan latihan up hill dalam permaian sepak bola pada club Abadi Talise.

\begin{tabular}{|c|c|c|c|c|c|}
\hline No & $\mathbf{X}_{\mathbf{1}}$ & $\mathbf{X}_{\mathbf{2}}$ & $\begin{array}{c}\mathbf{D} \\
\left(\mathbf{X}_{\mathbf{2}}-\mathbf{X}_{\mathbf{1}}\right)\end{array}$ & $\begin{array}{c}\mathbf{D} \\
(\mathbf{D}-\mathbf{M D})\end{array}$ & $\mathbf{d}^{\mathbf{2}}$ \\
\hline $\mathbf{1}$ & 24.20 & 26,70 & 2,50 & $-0,34$ & 0,1156 \\
\hline $\mathbf{2}$ & 26.27 & 29,77 & 3,50 & 0,66 & 0,4356 \\
\hline $\mathbf{3}$ & 26.30 & 28,80 & 2,50 & $-0,34$ & 0,1156 \\
\hline $\mathbf{4}$ & 25.15 & 27,15 & 2 & $-0,84$ & 0,7056 \\
\hline $\mathbf{5}$ & 24.25 & 26,75 & 2,50 & $-0,34$ & 0,1156 \\
\hline $\mathbf{6}$ & 25.40 & 28,40 & 3 & 0,16 & 0,0256 \\
\hline $\mathbf{7}$ & 26.36 & 28,86 & 2,50 & $-0,34$ & 0,1156 \\
\hline $\mathbf{8}$ & 24.38 & 27,58 & 3,20 & 0,36 & 0,1296 \\
\hline $\mathbf{9}$ & 26.40 & 29,60 & 3,20 & 0,36 & 0,1296 \\
\hline $\mathbf{1 0}$ & 24.10 & 27,60 & 3,50 & 0,66 & 0,4356 \\
\hline$\sum$ & $\mathbf{2 5 2 , 8 1}$ & $\mathbf{2 8 1 , 2 1}$ & $\mathbf{2 8 , 4}$ & $\mathbf{0}$ & $\mathbf{2 , 3 2 4}$ \\
\hline Mean & $\mathbf{2 5 , 2 8 1}$ & $\mathbf{2 8 , 4}$ & & & \\
\hline
\end{tabular}

Untuk mencari Mean Deviasi (MD) adalah sebagai berikut :

$$
\mathrm{MD}=\frac{\sum \boldsymbol{D}}{\mathrm{N}} \mathrm{MD}=\frac{28,4}{10} \mathrm{MD}=2,84
$$

Berdasarkan tabel 4 di atas diperoleh hasil keseluruhan tea awal dan tes akhir kelompok eksperimen adalah $\left(\sum X_{I}=252,81\right)$ sedangkan jumlah keseluruhan tes akhir $\left(\sum X_{2}=279,91\right)$ nilai beda dari tes awal $\left(\mathrm{X}_{1}\right)$ dan tes akhir $\left(\mathrm{X}_{2}\right)$ sebesar $\sum \mathrm{d}=28,4$ dan nilai varians dari tes awal dan tes akhir adalah $\sum \mathrm{d}^{2}=2,324$ selanjutnya dilakukan perhitungan uji $\boldsymbol{t}$ dengan rumus sebagai berikut: 
$t=\frac{M D}{\sqrt{\frac{\sum \mathrm{d} 2}{N(N-1)}}} t=\frac{2,84}{\sqrt{\frac{2,324}{10(10-1)}}} t=\frac{2,84}{\sqrt{\frac{2,324}{90}}} t=\frac{2,84}{0,161} t=17,64$

Dari perhitungan statistik $t_{\text {hitung }}=17,64$ dengan menggunakan taraf signifikan $5 \%$ dari d.b $=(\mathrm{N}-1)=10-1=9$ diperoleh nilai $t_{\text {tabel }}=2,268$ hal ini berarti nilai $t_{\text {hitung }}$ lebih besar dari $t_{\text {tabel }}$ atau 17,64 > 2,268 atau peningkatan antara tes awal dan tes akhir adalah 28,4 dengan mean deviasi sebanyak 2,84 atau peningkatannya sebanyak $28,4 \%$.

Latihan up hill merupakan bentuk latihan yang bertujuan untuk meningkatkan kekuatan dan power tungkai. Seperti halnya seorang pemain dalam khususnya cabang olahraga sepak bola saat melakukan gerakan shooting seorang harus dapat menendang bola semaksimal mungkin. Kekuatan dan kecepatan tendangan itu dapat dicapai ketika power tungkai yang mereka miliki sudah baik. Menurut Sukadiyanto (2002: 90) bahwa jika latihan dilakukan dengan sistematis, maka akan mempengaruhi dan meningkatkan komponen biomotor yang lain diantaranya, kecepatan, ketahanan otot, koordinasi, power, kelentukan dan ketangkasan. Kemudian dipertegas oleh Bompa \& Half (2009: 233) menyatakan power adalah hasil dari kedua kemampuan kecepatan maksimal dan kekuatan maksimal dalam waktu yang sesingkat mungkin. Mengingat pentingnya faktor power tungkai dalam segala cabang olahraga khususnya sepak bola, sehingga diperlukan upaya mencari beberapa metode latihan yang baik dalam peningkatan power tungkai dalam hal ini dilakukan dengan bentuk latihan up hill. Untuk selanjutnya akan dibahas dan diuraikan secara lengkap tentang hasil-hasil yang sudah diperoleh, yaitu sebagai berikut:

Kekuatan shooting club sepak bola talise, dapat diperoleh nilai $t_{\text {hitung }}=17,64$ dengan menggunakan taraf signifikan $5 \%$ dari d.b $=(\mathrm{N}-1)=10-1=9$ diperoleh nilai $t_{\text {tabel }}=2,268$ hal ini berarti nilai $t_{\text {hitung }}$ lebih besar dari $t_{\text {tabel }}$ atau 17,64> 2,268 atau peningkatan antara tes awal dan tes akhir adalah 28,4 dengan mean deviasi sebanyak 2,84 atau peningkatannya sebanyak $28,4 \%$.

Hasil perhitungan statistik dan angka-angka hasil perhitungan dengan rumus yang digunakan dalam penelitian ini dapat diketahui bahwa terdapat pengaruh dari latihan up hill terhadap kekuatan shooting dalam permainan sepak bola pada club Abadi Talise. Jika dibandingkan dengan hasil tes awal sebelum diberikan latihan up hill nilai rata-rata adalah 25,2810, sedangkan setelah diberikan perlakuan dengan latihan up hill meningkat menjadi 28,4, ini membuktikan bahwa dengan pemberian latihan up hill memberikan peningkatan terhadap kekuatan shooting dalam permainan sepak bola pada club Abadi Talise. Hal tersebut didasarkan pada teori yang digunakan dalam penelitian ini telah disebutkan bahwa latihan dan metode yang tepat akan dapat mempengaruhi kekuatan shooting dalam permainan sepak bola.

Melihat dari rerata yang didapatkan, dapat dikatakan bahwa hipotesis dalam penelitian ini telah diterima dan menjawab permasalahan serta mencapai tujuan dari penelitian ini. Penentuan

Dipublikasikan Oleh : 
populasi, sampel, variabel dan pelaksanaan kegiatan penelitian seperti tes awal, pemberian latihan up hill dan tes akhir kesemuanya didasarkan pada teori dan aturan yang ada sehingga memberikan dasar yang baik pada penelitian ini. Penentuan metode, instrumen dan langkah penelitian serta pelaksanan analisis dan pemilihan alat analisis sudah terbukti benar dan memberikan hasil yaitu tercapainya tujuan penelitian ini dengan hasil peningkatan sebesar $28,4 \%$.

\section{KESIMPULAN}

Hasil perhitungan statistik dan pembahasan maka dapat diambil suatu kesimpulan sebagai berikut : (1) Ada pengaruh yang signifikan pemberian latihan up hill terhadap kekuatan shooting dalam permainan sepak bola pada club Abadi Talise, dimana hasil analisis dan pembahasan hasil penelitian menunjukan bahwa $t_{\text {hitung }}=17,64$ lebih besar dari pada $t_{\text {tabel }}$ dengan taraf signifikan $5 \%$ dengan d.b $(\mathrm{N}-1)=(10-1)=9$ adalah 2,268 atau peningkatan antara tes awal dan tes akhir adalah 28,4 dengan mean deviasi sebanyak 2,84 atau peningkatan sebanyak 28,4\%. Sehingga hipotesis nol $\left(\mathrm{H}_{0}\right)$ dalam penelitian ini ditolak dan hipotesis alternatif $\left(\mathrm{H}_{\mathrm{a}}\right)$ diterima, dan (2) Pemberian latihan up hill memberi peningkatan yang berarti terhadap kekuatan shooting dalam permainan sepak bola pada club Abadi Talise dan cocok diterapkan khususnya pada atlet pemula karena terbukti dapat meningkatkan kondisi fisik khususnya pada power tungkai.

Berdasarkan hasil penelitian tersebut, maka disampaikan beberapa saran sebagai usaha tindak lanjut sebagai berikut : (1) Bagi guru-guru Penjas di SD dalam membina atau melatih latihan menendang dapat menggunakan bentuk latihan up hill, dan (2) Untuk peneliti yang berminat dapat meneliti kembali dan hasil penelitian bisa digunakan sebagai pembanding.

\section{REFERENSI}

Arikunto, S. (2006). Prosedur Penelitian Suatu Pendekatan Praktek. Jakarta : PT Rineka Cipta.

Hadi, S. (2001). Metode Rechearch. Jilid 3. Yogyakarka : Fakultas Psikologi UGM.

Sanders, M.R, (2005). The Relationship Between Maternal Self-Efficacy and Parenting Practices: Implications for Parent Training. Chilh: Care, Health, and Development, Vol 31(1) 6573.

Sukadiyanto. (2002). Pengantar Teori dan Metode Melatih Fisik. Yogyakarta. PKO FIK UNY

Bompa,T.O dan Gregory, H.G. (2009). Periodization: Theoryand Methodology of Training. Champaign, IL: Human Kinetics.

Dipublikasikan Oleh : 